\title{
EFFECT OF LEAF REMOVAL ON SUNFLOWER YIELD AND YIELD COMPONENTS AND SOME QUALITY CHARACTERS
}

\author{
Karadogan, T. and Akgün, I.
}

Süleyman Demirel University, Faculty of Agriculture, Department of Field Crops, 32260 Isparta, Turkey

\section{SUMMARY}

An experiment was conducted to determine the effects of the ratio of leaf removal from bottom of plants $(0,4,8$ and 12 leaves/plant) shortly before flowering on yield components and some quality characters of sunflower ecotypes.

According to ecotype averages, seed setting, seed yield, kernel ratio, crude oil and crude protein contents in seed, crude oil yield and crude protein yield changed with different degree of leaf removal. Head diameter, seed setting, seed yield, 1000-seed weight, kernel ratio, crude oil, crude protein content, crude oil yield and crude protein yield varied with degree of leaf defoliation of some ecotypes while these characters were not affected by defoliation in other ecotypes.

Key words: sunflower, leaf removal, yield components, quality

\section{INTRODUCTION}

In many countries sunflower (Helianthus annuus L.) is mainly grown for its edible oil as well as for a snack. The main objective in crop production is to obtain high yielding and high quality crop. Achievement of this goal requires the use of appropriate cultivar for a particular region, high quality seed and application of proper management practices (Majid and Schnettier, 1988; Karadogan et al., 1998).

Sunflower characters make it suitable for examination of plant growth in physiological experiment. Helianthus annuus L., particularly at the seedling stage, has long been used for plant physiological investigations (Pereira, 1978). Lately, however, importance has been devoted to the whole plant and the relationship between individual leaves and yield (Johnson, 1972; Pereira, 1978; Schneiter et al., 1987;

* Corresponding author: Phone: 9024621146 28; Fax: 9024621123716 93; e-mail: iakgun@ziraat.sdu.edu.tr 
Sadras et al., 2000). Leaves are vitally essential organs for photosynthesis, which is a major process affecting crop growth rates and is affected by either the number or the area of the leaves. Since the productivity of a plant depends on the efficiency of its photosynthetic processes and therefore on the extent of its photosynthetic surface, the growth and development of leaves have a profound impact on the yield of the plant. In addition, leaves also play a vital part in controlling water loss by plants.

In experiments related to this subject it is stated that the effects of leaf removal on sunflower yield and yield components change according to the number of leaf removed (Sackston, 1959), removal time (Schneiter et al., 1987) and the position of the removed leaf (Johnson, 1972). It is also stated that reactions differ from one cultivar to another (Pereira, 1978).

Experiments about artificial leaf removal were conducted on other plants such as sugarcane (Singh and Singh, 1984), peanut (Jones et al., 1982), chickpea (Pandey, 1984), sorghum (Rajewski et al., 1991), soybean (Diogo et al., 1997) and it was stated that leaf removal affects the yield.

In the field, leaf area decreases because of drought, hail, insect and disease or as a result of senescence. Although lower leaves do not make large contribution to photosynthesis because they are obscured by upper leaves, they do cause loss by respiration. In some parts of our country different numbers of leaves are removed, especially during the periods after flowering. But in reality the effect of this leaf removal on plant growth is not known. Thus, we tried to assess the reaction of sunflower yield and yield components on leaf area reduction.

In this experiment we studied the effects of leaf removal, in different numbers, in different ecotypes and at the beginning of flowering, on sunflower yield and yield components and quality.

Table 1: Sunflower ecotypes used in the experiment

\begin{tabular}{lcc}
\hline Ecotype & Center of origin & Maturity \\
\hline Amasya & Suluova-Amasya & Late \\
Uşak & Banaz- Uşak & Late \\
Kirşehir & Oluklu village Kirşehir & Late \\
Erzurum & Pasinler & Medium early \\
Igdir-2 & Çalpalan village-lgdir & Medium early \\
Çorum-2 & Sungurlu-Çorum & Late \\
Edirne -1 & Hatip village-Edirne & Late \\
Çorum-1 & Alaca-Çorum & Late \\
Hat-1 & Atatürk Univ. Agricultural Faculty & Medium early \\
Igdir-1 & Enginalan village-lgdir & Late \\
\hline
\end{tabular}

\section{MATERIAL AND METHODS}

A field experiment was carried out at Atatürk University Research Farm in Erzurum, Eastern Anatolia, Turkey (395 $55^{\prime}$ N, 41 ${ }^{\circ} 16^{\prime} \mathrm{E}$, altitude $1950 \mathrm{~m}$ ). The 
experiment included 10 sunflower ecotypes and information about the ecotypes used in the experiment are presented in Table 1.

The soils in the experimental plots are clays with neutral characteristics, rich in potassium, poor in nitrogen and organic material, medium-provided with phosphorus. Climatic conditions during the experimental years were similar to the longterm averages; the average temperature in the growth period was $14.8^{\circ} \mathrm{C}$, the precipitation was $174.1 \mathrm{~mm}$, and the relative humidity was $57.6 \%$.

The experiment was established in a randomized block design with 3 replications, with the 10 sunflower ecotypes as the first factor and leaf removal level (from bottom $0,4,8,12$ leaves/plant) as the second factor. Sowing was performed in rows $70 \mathrm{~cm}$ apart; plant distance within the row was $40 \mathrm{~cm}$. Each row had 12 plants, each plot consisted of 4 rows. Fertilizers $\left(8.5 \mathrm{~kg} / \mathrm{da} \mathrm{N}\right.$ and $\left.9 \mathrm{~kg} / \mathrm{da} \mathrm{P}_{2} \mathrm{O}_{5}\right)$ were applied together with sowing (Öden, 1991) and cultivation practices were applied when necessary throughout the growth period. The experiment area was irrigated when the available moisture reached $20 \%$ of field water capacity.

As soon as flowering head was seen in every plot, 0, 4, 8 and 12 leaves were removed from the bottom of the plants in each plot.

At harvest time, the plants in the two middle rows (a total of 24 plants) were collected and taken to the laboratory and yield parameters were determined after the heads had been threshed and the seeds had been dried to a moisture content of about $7 \%$.

The following parameters were examined (Günel, 1972; Karadogan and Özgödek, 1994).

Head size: Head diameters of the plants from the harvested area were measured and the averages were calculated in $\mathrm{cm}$.

Seed setting: Head diameter "R" and the diameter of head center "r" are calculated according to the formula given below:

Ratio of seed setting $(\%)=100-\left(\mathrm{r}^{2} / \mathrm{R}^{2}\right) \times 100$

Grain weight: 100 -seed samples were taken 4 times were taken from each plot and weighed.

Kernel ratio: Kernel ratio was calculated according to the formula below:

Kernel ratio (\%): [kernel weight $(\mathrm{g}) /$ grain weight $(\mathrm{g})] \times 100$

Seed yield: Seeds of all plants from the harvested area were weighed, plot yield was then found and the result was calculated as seen yield per decare $(\mathrm{kg} / \mathrm{da})$.

Ratio of crude oil: Crude oil ratio was determined by the Soxhlet method after extraction with petrol ether.

Ratio of crude protein: $\mathrm{N}$ quantity in seed was determined by the Kjeldahl method and the ratio of crude protein was calculated by multiplying the result by 6.25 .

Crude protein yield: Found by multiplying seed yield per decare by crude protein ratio.

Crude oil yield: Found by multiplying crude oil ratio by seed yield per decare. 


\section{RESULTS}

\section{Head size}

The head diameter increased simultaneously with the increase in the number of removed leaves, but the impact was not statistically significant (Table 2).

Table 2: Effects of leaf removal on head diameter, seed setting, seed yield and 1000-grain weight of sunflowers

\begin{tabular}{lcccc}
\hline $\begin{array}{l}\text { Number of } \\
\text { removed leaves }\end{array}$ & $\begin{array}{c}\text { Head diameter } \\
(\mathrm{cm})\end{array}$ & $\begin{array}{c}\text { Seed setting } \\
(\%)\end{array}$ & $\begin{array}{c}\text { Seed yield } \\
(\mathrm{kg} / \mathrm{da})\end{array}$ & $\begin{array}{c}1000 \text {-grain weight } \\
(\mathrm{g})\end{array}$ \\
\hline 0 & 17.8 & $98.40 \mathrm{ab}$ & $227.95 \mathrm{~b}$ & 123.27 \\
4 & 17.9 & $98.17 \mathrm{~b}$ & $250.12 \mathrm{a}$ & 123.77 \\
8 & 18.0 & $98.90 \mathrm{a}$ & $270.20 \mathrm{a}$ & 125.73 \\
12 & 18.2 & $98.51 \mathrm{ab}$ & $266.56 \mathrm{a}$ & 123.80 \\
LSD & $\mathrm{ns}^{(1)}$ & 0.5042 & 21.69 & $\mathrm{~ns}$ \\
\hline
\end{tabular}

(1) nonsignificant

Change of head diameter due to the number of removed leaves showed significant changes in certain ecotypes $(\mathrm{p}<0.01)$. While the head diameter decreased with leaf removal in the ecotypes Igdir-2, Hat-1, Çorum-1and Edirne-1, there were increases in the ecotypes Uşak, Kirşehir, Igdir-1 and Erzurum; there were no changes in head diameter in the other ecotypes (Figure 1). Leaf removal $\times$ ecotype interaction was found to be significant $(\mathrm{p}<0.01)$.

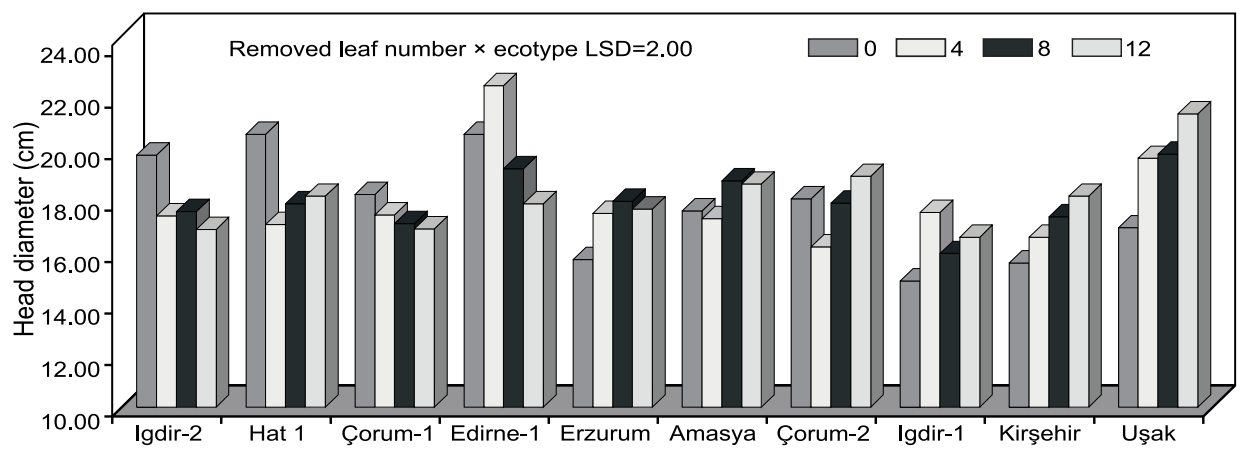

Figure 1: Change of sunflower head diameter with removed leaf number

\section{Seed setting ratio}

With leaf removal, seed setting showed considerable changes. The removal of 8 leaves had the highest effect on seed setting. The removal of 12 leaves did not lead to a statistical important change when compared with the removal of 8 leaves (Table 2 ). The effect of leaf removal on seed setting also showed considerable changes in dependence of the ecotype $(\mathrm{p}<0.01)$. Decreases is seed setting due to leaf removal occurred in Çorum-1, Hat-1, Amasya and Igdir-1 ecotypes, and increases occurred in Kirşehir, Uşak and Edirne-1 ecotypes (Figure 2). In the other ecotypes, the effect 
of leaf removal on seed setting was not significant. The ecotype $\times$ leaf removal interaction was found to be significant $(\mathrm{p}<0.01)$.

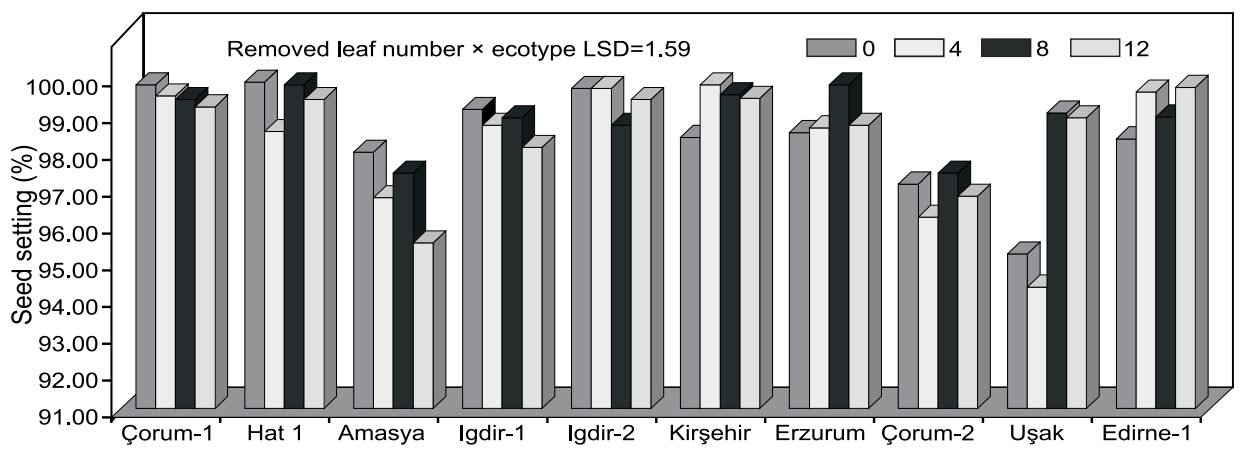

Figure 2: Change of grain setting of sunflower ecotypes with removed leaf number

\section{Seed yield}

Generally, the seed yield of the plants with no leaf removal was lower than that of the plants with leaf removal (Table 2). The effect of leaf removal showed variations due to the ecotypes $(\mathrm{p}<0.01)$. Highest seed yields were obtained with the removal of 8 bottom leaves from the ecotypes Edirne-1, Amasya, Uşak, and Erzurum.

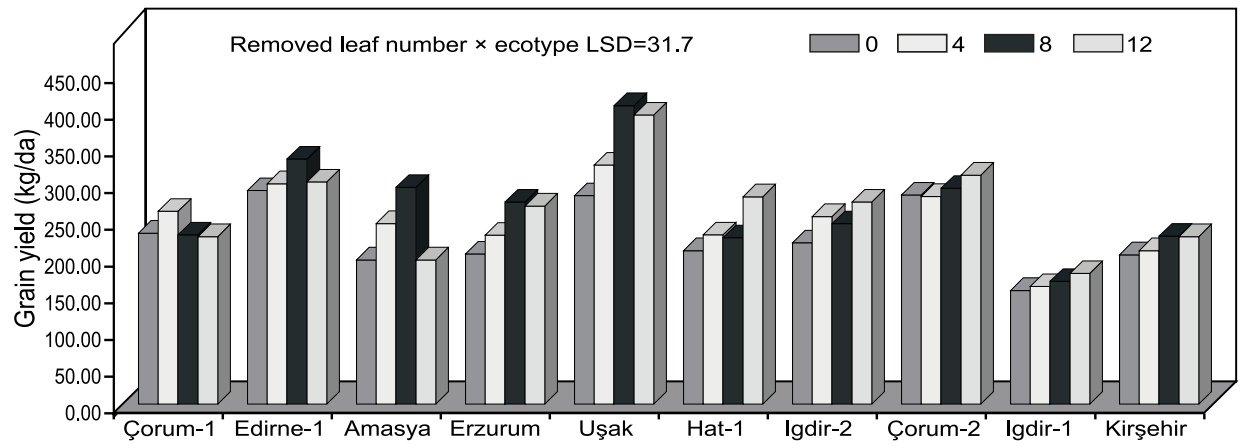

Figure 3: Change of seed yield of sunflower ecotypes with removed leaf number

Highest seed yields with the removal of 12 leaves were found in the ecotypes Hat-1, Igdir-2, Çorum-2, and Igdir-1, and with the removal of 4 leaves in the ecotype Çorum-1 (Figure 3 ). The ecotype $\times$ leaf removal interaction was found to be nonsignificant.

\section{Grain weight}

Statistically, the effect of leaf removal on the 1000-seed weight was nonsignificant. Yet, in the case of the removal of 8 bottom leaves, the average 1000-seed weight was increased (Table 2). The effect of leaf removal on 1000-seed weigh 
showed variations in dependence of the ecotypes $(\mathrm{p}<0.01)$. The 1000 -seed weight decreased simultaneously with the number of removed leaves in the case of the ecotypes Hat-1, Kirşehir and Çorum-1; increase in 1000-seed weight was observed in the other ecotypes (Figure 4).

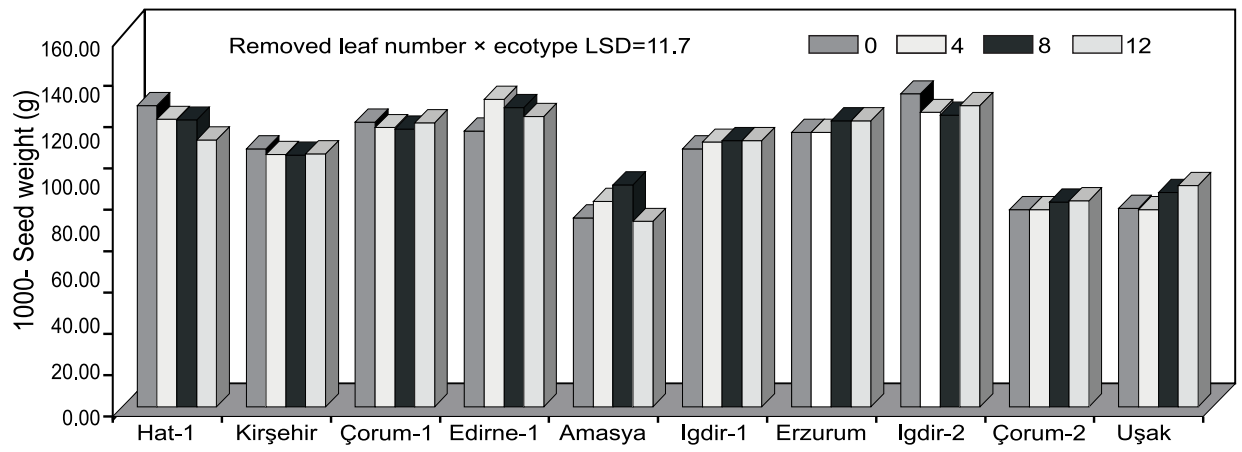

Figure 4: Change of 1000-seed weight of sunflower ecotypes removed leaf number

Highest 1000-seed weights were obtained with the removal of 8 leaves of the ecotype Amasya and 4 leaves of the ecotype Edirne-1. The 1000-seed weight of the other ecotypes did not change with leaf removal and the interaction was found to be nonsignificant.

\section{Kernel ratio}

The studied ecotypes showed considerable changes in the kernel ratio. The highest ratio (56.05\%) was acquired by removing 8 leaves. However, this variant was not significantly different from the other leaf removal variants $(\mathrm{P}<0.05)$. The lowest kernel ratio (54.10\%) was determined from the plants with no leaf removal (Table 3). The ecotypes varied in the kernel ratio in response to leaf removal $(\mathrm{P}<0.01)$. While the kernel ratio decreased due to severe leaf removal in the ecotypes Edirne-1, Uşak and Igdir-2, increases were observed in the others ecotypes (Figure 5).

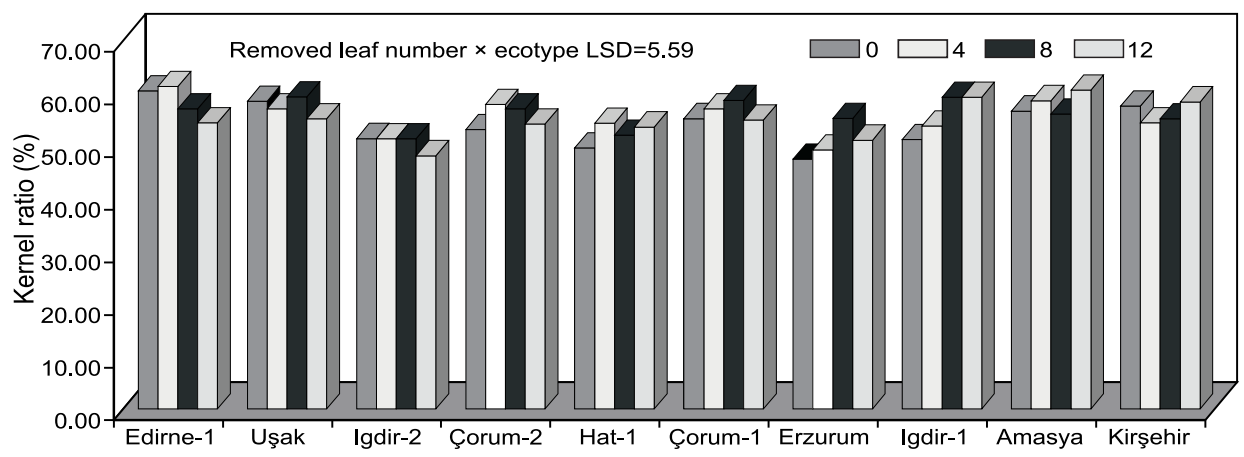

Figure 5: Change of kernel ratio in sunflower with removed leaf number 
Reactions of the different ecotypes to leaf removal were different from one another and interaction was found to be statistically significant $(\mathrm{P}<0.01)$.

Table 3: Effects of sunflower leaf removal on kernel ratio, crude oil, crude protein content, crude protein yield and crude oil yield

\begin{tabular}{lccccc}
\hline $\begin{array}{l}\text { Number of } \\
\text { removed leaves }\end{array}$ & $\begin{array}{c}\text { Kernel ratio } \\
(\%)\end{array}$ & $\begin{array}{c}\text { Crude protein } \\
\text { content }(\%)\end{array}$ & $\begin{array}{c}\text { Crude protein } \\
\text { yield }(\mathrm{kg} / \mathrm{da})\end{array}$ & $\begin{array}{c}\text { Crude oil } \\
\text { content }(\%)\end{array}$ & $\begin{array}{c}\text { Crude oil yield } \\
(\mathrm{kg} / \mathrm{da})\end{array}$ \\
\hline 0 & $54.10 \mathrm{~b}$ & $21.15 \mathrm{~b}$ & $49.25 \mathrm{~b}$ & $19.40 \mathrm{a}$ & $44.11 \mathrm{c}$ \\
4 & $55.43 \mathrm{ab}$ & $21.68 \mathrm{ab}$ & $54.69 \mathrm{ab}$ & $19.20 \mathrm{a}$ & $48.04 \mathrm{bc}$ \\
8 & $56.05 \mathrm{a}$ & $22.38 \mathrm{a}$ & $60.94 \mathrm{a}$ & $19.23 \mathrm{a}$ & $53.20 \mathrm{a}$ \\
12 & $54.90 \mathrm{ab}$ & $22.33 \mathrm{a}$ & $59.84 \mathrm{a}$ & $18.34 \mathrm{~b}$ & $49.23 \mathrm{ab}$ \\
LSD & 1.414 & 1.055 & 6.179 & 0.5142 & 4.437 \\
\hline
\end{tabular}

\section{Crude protein ratio}

The crude protein ratio increased simultaneously with the increase in the average number of leaves removed $(\mathrm{p}<0.01)$. When compared with the plants whose leaves were not removed, the crude protein ratio in seeds of the plants with 8 and 12 removed leaves was very high (Table 3 ).

The crude protein ratio showed significant differences among the ecotypes $(\mathrm{p}<0.01)$. While the crude protein ratio in the ecotypes Kirşehir, Igdir-2, Amasya and Igdir-1 decreased in response to leaf removal, increases were observed in the other ecotypes (Figure 6).

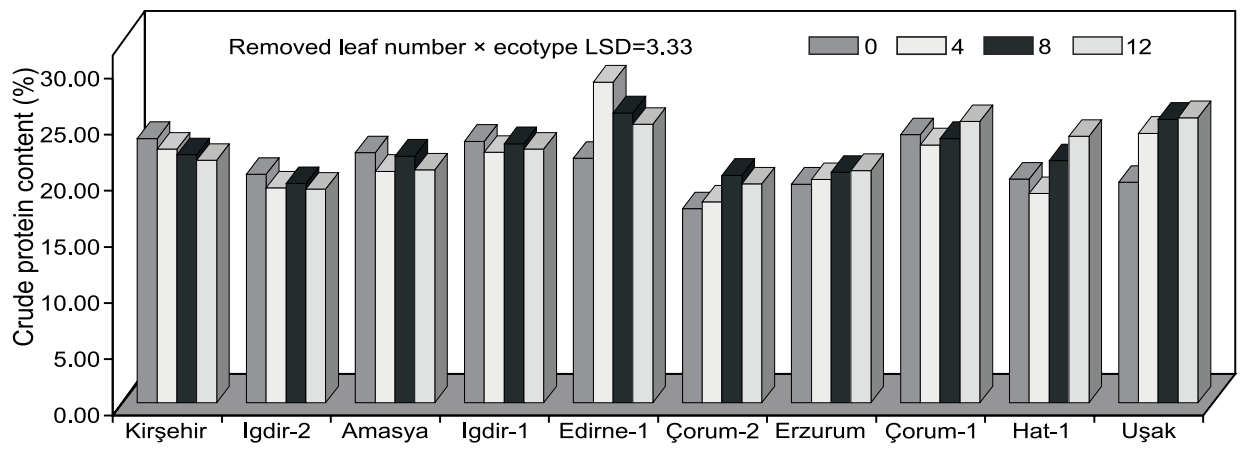

Figure 6: Change of crude protein content of sunflower ecotypes with removed leaf number

Highest crude protein ratios and significant interactions $(p<0.01)$ were observed in response to the removal of 4 leaves in the case of the ecotype Edirne- 1 and the removal of 8 leaves in the case of the ecotype Çorum-2.

\section{Crude protein yield}

Leaf removal significantly affected the crude protein yield of sunflower $(\mathrm{p}<0.01)$. The average crude protein yield $(49.25 \mathrm{~kg} / \mathrm{da})$ per decare was lower in the plants whose leaves were not removed, and the differences between this result and those obtained with the removal of 8 and 12 leaves were found to be significant. 
The effect of leaf removal on crude protein yield differed in dependence of the ecotype $(\mathrm{p}<0.01)$. In the case of Igdir-1 ecotype, leaf removal increased crude protein yield. In other ecotypes (Çorum-1, Igdir-2, Çorum-2, and Kirşehir) the effect of leaf removal on crude protein yield per decare was not significant statistically. Removal of 8 leaves in Edirne-1, Uşak, Erzurum and Amasya ecotypes and 12 leaves in Hat-1 brought highest crude protein yields per decare (Figure 7). Ecotype $\times$ leaf removal interaction was significant.

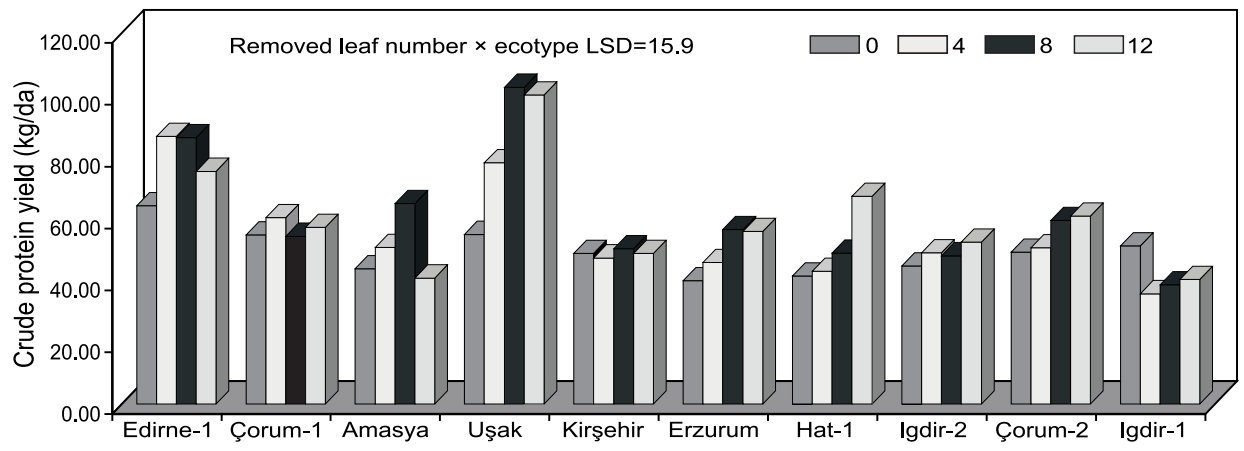

Figure 7: Change of crude protein yield of sunflower ecotypes with removed leaf number

\section{Crude oil ratio}

Increase in the number of removed leaves tended to decrease the crude oil ratio. The decrease was not important until 8 and 12 leaves were removed (Figure 8 ). The crude oil ratios in these variants decreased considerably when compared with the other variants (Table 3 ).

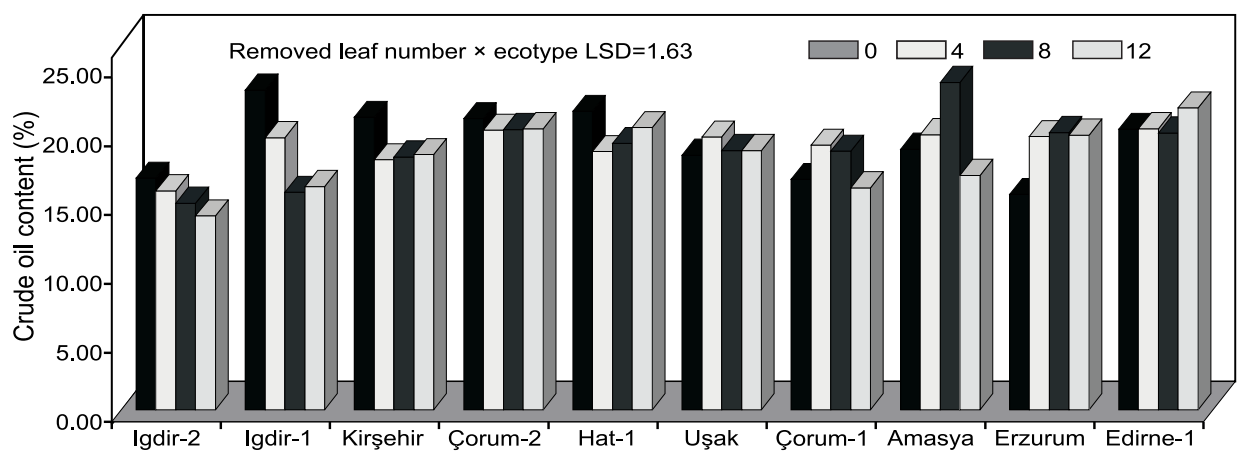

Figure 8: Change of crude oil content of sunflower ecotypes with removed leaf number

The effect of leaf removal on crude oil proportion showed considerable differences in dependence of the ecotype $(\mathrm{p}<0.01)$. Leaf removal affected significantly $(p<0.01)$ the crude oil proportion in Edirne-1, Uşak and Çorum-2 ecotypes. The crude oil proportion in seed of Igdir-1, Kirşehir, Igdir-2 and Hat-1 ecotypes when 
leaves were not removed was higher than that in the other ecotypes with 4 or 8 leaves removed. The ecotype $\times$ treatment interaction was found to be significant.

\section{Crude oil yield}

The crude oil yield per decare varied highly $(\mathrm{p}<0.01)$ in dependence of the number of removed. The highest crude oil yield $(53.20 \mathrm{~kg} / \mathrm{da})$ was achieved when 8 leaves were removed. The lowest crude oil yield (44.11 kg/da) was found in the control plots (Table 3).

The change in crude oil yield of the sunflower ecotypes was related with the number of removed leaves. The interaction between the ecotypes and the number of removed leaves was significant $(\mathrm{p}<0.01)$. With the exception of the ecotype Igdir-1, leaf removal increased the crude oil yield (Figure 9 ).

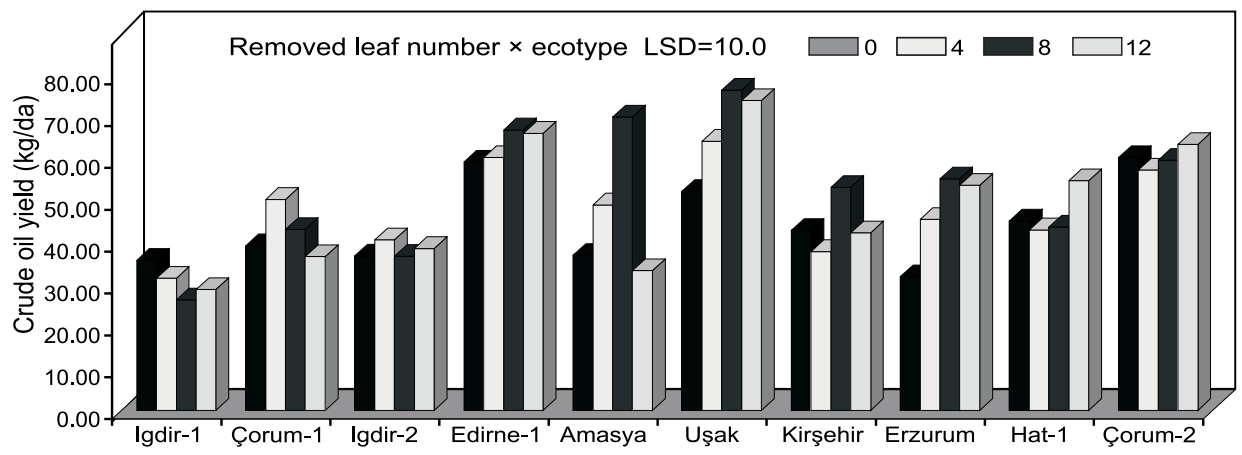

Figure 9: Change of crude oil yield of sunflower ecotypes with removed leaf number

\section{DISCUSSION}

In this research it was found that the removal of bottom leaves had significant effects on seed setting rate, seed yield, kernel ratio, crude protein and crude oil rates and crude protein and crude oil yields per decar. Leaf removal had no significant effect on head size and 1000-grain weight, but the average values of these parameters in the plants with removed leaves were higher than those in control plants. Effect of leaf removal varied with the ecotype (Figures 1, 2, 3, 4, 5, 6, 7, 8 and 9). It is assumed that this interaction derives from the height of ecotypes, numbers of branches and leaves (Karadogan and Özgödek, 1994), leaf angle and the differences in leaf area. As a matter of fact, while investigating physiological properties of semi-dwarf and standard-height sunflowers, Shulgin and Klimov (1974) found that the semi-dwarf forms had better distribution of assimilates throughout the organs and a more active photosynthetic apparatus. The effect of leaf removal on the examined features was especially apparent in the ecotypes with a large number of leaves and with erect leaves (such as Amasya, Kirşehir, Uşak, Edirne ). In spite of 
the fact that lower leaves do not participate in photosynthesis because of the shading by upper leaves, their removal causes positive increases in the examined features.

In earlier studies about the topic, it had been stated that leaf removal affects head size, seed yield, 1000-grain weight, kernel rate, crude oil rate and oil yield (Johnson, 1972; Schneiter et al., 1987). Pereira (1978) reported that the yield of late hybrids was less adversely affected by leaf removal than that of early hybrids. In addition, timing of sunflower leaf removal has has in itself an effect on yield and yield components. Sackston (1959) who defoliated plants at the seedling, flowering, and maturing stages found that the treatment was most injurious when carried out at the flowering stage.

Leaf removal at various times significantly reduces the time to first anthesis (12 to $13 \%$ ), total floret number ( 16 to $17 \%$ ) and it vastly increases the receptacle area (Kim, 1990).

In conclusion, it seems impossible to make a definite statement that sunflower yield, yield components and quality are unaffected by the removal of up to 8 leaves per plant while the removal of more than 8 leaves does affect yield and quality.

\section{REFERENCES}

Diogo, A.M., Sediyama, T., Rocha, V.S., and Sediyama, C.S., 1997. Effect of leaf removal at various stages of development on seed yield and other agronomic characteristics of soyabeans (Glycine max (L.) Merrill). Revista- Ceres. 44: 253, 272-285.

Günel, E., 1972. Erzurum şartlarinda gübreleme, ekim mesafe ve araliklarinin ayçiçeginin verimine ve bazi zirai karakterlerine etkisi üzerinde bir araştirma. Atatürk Üni. Zir. Fak. Der. 3: 53-67.

Johnson, J.R., 1972. Effect of artificial defoliation on sunflower yields and other characderistics. Argon. J. 64: 688-689.

Jones, J.W., Barfield, C.S., Boote, K.J., Smerage, G.H. and Mangold, J., 1982. Photosynthetic recovery of peanuts to defoliation at various growth stages. Crop Science 741-746.

Karadogan, T., Carkci, K. and Özer, H., 1998. An investigation on differences in the quality of sunflower seeds in relation to their position on the head. Helia 21(29): 121-130.

Karadogan, T. and Özgöbek, Z., 1994. Çerezlik karakterdeki bazi ayçiçegi ekotiplerinin verim ve verim unsurlari üzerine bir araştirma. Atatürk Üni. Zir. Fak. Der. (1994) 25: 188-201.

Kim, J.R., 1990. Growth and development in the oilseed sunflower (Helianthus annuus L.). PhD Thesis, University of New South Wales, Australia DAI-B 51/02, p. 513.

Majid, H.R. and Schnettier, A.A., 1988. Yield and quality of semi-dwarf and standard height sunflower hybrids and five plant populations. Agron. J. 79: 581-584.

Öden, Ö., 1991. Pasinler ve Igdir ovalarinda ayçiçeginin azotlu ve fosforlu gübre istegi. Erzurum Bölge Toprak - Su Araş. Ens. Müd. Yayinlari No. 30, Erzurum.

Pandey, R.K., 1984. Influence of source and sink removal on seed yield of chickpea (Cicer arietinum L.). Field Crops Research 8(3): 159-168.

Pereira, A.S.R., 1978. Effect of leaf removal on yield components in sunflower. Neth. J. Agric. Sci. 26: 133-144.

Rajewski, J.F., Francis, C.A. and Eastin, J.D., 1991. Differential responses to defoliation of grain sorghum yield components and yield-related traits. Crop Science 31: 3, 561-567.

Sackston, W.E., 1959. Effect of artificial defoliation on sunflower. Can. J. Plant Sci. 39: 108-118.

Sadras, V.O., Echarte, L. and Andrade, F.H., 2000. Profiles of leaf senescence during reproductive growth of sunflower and maize. Annals of Botany 85: 187-195.

Schneiter, A., Jones, M. and Hammond, J.J., 1987. Simulated hail research in sunflower: Defoliation. Agron. J. 79: 431-434. 
Shulgin, I.A. and Klimov, S.V., 1974. Physiological characteristics of long-stemmed and shortstemmed forms of sunflower. Soviet Pl. Physiol. 21(5): 739-744.

Singh, R.P. and Singh, P.P., 1984. Quality of juice and commercial cane sugar as influenced by crop canopy in sugarcane. Indian Sugar 34: 1, 21-28.

\title{
EFECTO DE LA REMOCIÓN DE HOJAS SOBRE EL RENDIMIENTO DEL GIRASOL Y SUS COMPONENTES Y ALGUNOS CARACTERES DE CALIDAD
}

\author{
RESUMEN
}

Se condujo un experimento para determinar los efectos de la remoción de hojas a partir de la base de las plantas $(0,4,8$ y 12 hojas/planta) poco antes de la floración sobre los componentes del rendimiento y algunos caracteres de calidad de ecotipos de girasol.

De acuerdo con los promedios mostrados por estos ecotipos, el cuaje, rendimiento de semilla, porcentaje de pepita, contenido de aceite y contenido de proteína cruda de la semilla, rendimiento de aceite y rendimiento de proteína cruda, variaron con los diferentes niveles de remoción foliar. El diámetro de capítulo, cuaje, rendimiento de semilla, peso de mil semillas, porcentaje de pepita, contenido de aceite, contenido de proteína cruda, rendimiento de aceite y rendimiento de proteína cruda variaron con el grado de defoliación en algunos ecotipos mientras que estas características no fueron afectadas por la defoliación en otros ecotipos.

\section{EFFET DE L'ÉLIMINATION DES FEUILLES SUR LE RENDEMENT, LES COMPOSANTES DU RENDEMENT ET CERTAINES CARACTÉRISTIQUES QUALITATIVES DU TOURNESOL}

\author{
RÉSUMÉ
}

L'expérience a été conduite pour déterminer l'effet d'une suppression des feuilles de la partie basse des plantes $(0,4,8$ et 12 unités foliaires par plante) dans la période précédant immédiatement la floraison, sur les composantes du rendement et certaines caractéristiques qualitatives d'écotypes de tournesol.

Sur la moyenne des écotypes, le nombre de graines, le rendement en graines, le rapport amande/grain, la teneur en huile et en protéine des graines, le rendement en huile et en protéine, ont été modifiés selon le degré de suppression des feuilles.

Pour certains écotypes, le diamètre du capitule, le nombre de graine, le rendement en graines, le rapport amande/grain, la teneur en huile et en protéine ds graines, le rendement en huile et en protéine ont été modifiés par le degré de suppression des feuilles, alors que pour d'autres écotypes, ces caractères n'ont pas été affectés. 
